\title{
FAMILY REUNIFICATION AND THE SECURITY STATE
}

\author{
Kerry Abrams*
}

When does an individual's interest in reunification with a family member outweigh a sovereign nation's interest in controlling its borders? This question, long debated by courts, legislators, and policy-makers, is now emerging as an important civil rights issue for the general public. President Donald J. Trump's recent executive orders banning immigrants from several predominantly-Muslim countries had the effect of separating spouses from spouses, parents from children, and children from grandparents. ${ }^{1}$ These separations were quickly seized upon in the media as violations of human decency and civil rights. ${ }^{2}$ Although courts granted injunctions of the orders primarily due to the likelihood that enforcement of them would violate the procedural due process rights of green-card holders and the free exercise of religion rights of Muslims, the issue of family reunification was raised in some of the cases and mentioned briefly in court

* Professor of Law, University of Virginia. Thank you to Kristin Collins, Brandon Garrett, Jill Hasday, and Doug NeJaime for their helpful comments and to the Association of American Law Schools for providing a forum to present the paper.

1. See Executive Order: Protecting the Nation from Foreign Terrorist Entry into the United States (Jan. 27, 2017); and revised version (Mar. 6, 2017).

2. See, e.g., Elise Foley, Trump's Executive Order Is Already Hurting Refugees, Muslims, and Families, HUFFINGTON POST (Jan. 28, 2017). http://www.huffingtonpost.com /entry/trump-muslim-refugee-ban_us_588cb24ee4b0176377948a09 (quoting a woman sponsoring a Syrian refugee family as saying, "Just imagining raising a child in a refugee camp environment and then being told you could see your family again, you could be reunited with your mom and your daughter's grandma and being told 'No, sorry, you're three days too late for that' - I can't imagine what that's like"); Amy La Porte \& Azadeh Ansari, They Were Hoping To Get to the U.S. - and then Trump Banned Them, CNN POLITICS (Jan. 29, 2017), http://www.cnn.com/2017/01/28/politics/trump-visa-ban-familiesrefugees-stories/ (relating stories of several families separated by the travel ban); Michelle Gallardo \& Eric Horng, Families Splintered, Stranded by Trump's Immigration Order, ABC NEWs (Jan. 30, 2017), http://abc7chicago.com/news/families-splintered-stranded-bytrumps-immigration-order/1728752/ (quoting that sister of a refugee who was detained as saying, "This is just a nightmare I'll wake up from, and this is not true. This is not happening. I wish I can do that."). 
opinions. ${ }^{3}$ The family reunification question will likely be addressed more fully soon, either in the cases already filed or cases brought in response to new, more carefully crafted orders.

When a court does directly address this issue, what will the answer be? I argue that today, courts will recognize family reunification as an interest of constitutional import, and will balance that interest against the genuine national security interests of the government. Understanding why this is so requires an analysis of the shifting and complex relationship that the right to family unity and the government's power over immigration have had since our nation's founding. These two principles have always been in conflict, but their relative strength has waxed and waned over time. Today, our constitutional jurisprudence has become nuanced enough that the individual rights of families can be balanced with the interests of the state.

In this Article, I trace the history of this relationship, exploring the major shifts and upheavals. I argue that family rights and the federal immigration power have had three very different relationships over time. In the first period, family rights were robust but extraconstitutional, a bedrock assumption of how American democracy operated. Regardless of whether the nation was in a mode of conquest and expansion (and therefore encouraged European migration to help "civilize" the new nation), or in a mode of restriction (actively circumscribing immigration), family relationships were assumed by courts, administrators, and citizens to be important enough that they could override the state's interest in regulating its borders. In the second period, which began roughly with the quota system in the 1920 s and continued roughly through the 1980 s, courts shifted to conceiving family rights and the immigration power as conflicting with one another, and when pressed they usually found that the government's interest in restricting immigration and protecting its borders outweighed the interests of individual families in reuniting. Most recently, as family law itself has become "constitutionalized," a new understanding is emerging, whereby individual family members have a constitutionally protected interest in their relationships, and the state's national security and border regulation interests are recognized still as significant but

3. See, e.g., Washington v. Trump, 847 F.3d 1151, 1166 (9th Cir. 2017) (per curiam) (noting that, even if green card holders were not covered by the executive order, "applicants who have a relationship with a U.S. resident" might have claims to assert). 
must be balanced with these interests. This latest balancing trend is not unique to the particular relationship between family reunification and the immigration power, but that relationship is an important, and underappreciated, example. ${ }^{4}$

This argument necessarily paints history with a broad brush. It goes without saying that the trends I observe here were never universal and always contested, as many scholars have explored at length elsewhere. ${ }^{5}$ Today's family law, constitutional law, and even immigration law still contain vestiges of these other periods. ${ }^{6}$ I argue, however, that over large periods of time, we can begin to discern changes in the tide: a change in the common understanding of "rights" in general and "family rights" in particular, a change in courts' understanding of the role of the federal government in national security and border regulation, and a change in the relationship of individual rights to this power.

This argument proceeds as follows. Part I explores the common law concept of "family rights" and their relation to migration during, first, a time of expansion, and second, a time of restriction. Part II explores the rise of what I call the "security state," and the use of the plenary power doctrine to bolster congressional and executive power at the expense of family unity. Part III examines recent United States Supreme Court cases that call this doctrine into question, showing how, taken together, they point to a new understanding of the balance between the

4. For a classic examination of the rise of constitutional balancing, see T. Alexander Aleinikoff, Constitutional Law in the Age of Balancing, 96 YALE L.J. 943 (1987).

5. See CANDICE LeWIS BREDbenNer, A NATIONAlity OF Her OWN (1998); NANCY F. COTt, Public Vows: A History of MARriage AND the NATION (2000); MARTHA MABIE GARDNER, THE QuAlities of A CITIZEN: WOMEN, IMMIGRATION, AND CITIZENSHIP, 1870-1965 (2005); GEORGE ANTHONY PEFFER, IF THEY DON'T BRING Their Women Here: Chinese Female ImMigration Before EXClusion (1999); Janet M. Calvo, Spouse-Based Immigration Laws: The Legacy of Coverture, 28 SAN DIEGO L. REV. 593 (1991); Kristin A. Collins, Illegitimate Borders: Jus Sanguinis Citizenship and the Legal Construction of Family, Race, and Nation, 123 YALE L.J. 2134 (2014); Rose Cuison Villazor, The Other Loving: Uncovering the Federal Government's Racial Regulation of Marriage, 86 N.Y.U. L. REV. 1361 (2011); Leti Volpp, Divesting Citizenship: On Asian American History and the Loss of Citizenship Through Marriage, 53 UCLA L. REV. 405 (2005).

6. See, e.g., Jill Elaine Hasday, The Canon of Family Law, 57 STAN. L. REV. 825, 841 (2004) (showing that family law scholars often overstate the extent to which coverture has been "vanquished and excised from the law of marriage"); Reva B. Siegel, The Modernization of Marital Status Law: Adjudicating Women's Wives' Rights to Earnings, 1860-1930, 82 GEO. L.J. 2127, 2210 (showing that "when a society undertakes to disestablish caste relations, it may instead translate them from an antiquated and therefore socially dissonant discourse to a contemporary and socially acceptable discourse"). 
government's interest in maintaining its borders and citizens' interests in maintaining their families. Family reunification is a right, but it does not outweigh legitimate national security interests. Congress and the Executive enjoy power over immigration, but not to the extent that they can arbitrarily ignore family ties.

\section{THE AGE OF THE UNITARY FAMILY}

The text of the United States Constitution makes no mention of family. The Bill of Rights enumerates the right of the people to peaceably assemble, to keep and bear arms, to be secure in their persons against unreasonable searches and seizures, and many other specific rights, but the right to marry, the right to beget or bear children, the right to make decisions about the welfare of one's child, or the right to live with a family member are nowhere mentioned.

Also absent from the U.S. Constitution is a general power over immigration. True, the Migration Clause precluded Congress from prohibiting the migration or importation of people prior to the year $1808,{ }^{8}$ but this clause was widely understood to euphemistically refer to the slave trade. ${ }^{9}$ The Constitution does grant Congress the power to "establish a uniform rule of Naturalization" (e.g., a rule for creating new citizens $)^{10}$ and with Reconstruction came the Fourteenth Amendment, which provided citizenship to anyone born on U.S. soil. ${ }^{11}$ A general authority over the admission and removal of noncitizens, however, is conspicuously absent. ${ }^{12}$

The textual absence of family and immigration from the Constitution reflects the social and political conditions under

7. Bruce Hafen, The Constitutional Status of Marriage, Kinship, and Sexual Privacy: Balancing the Individual and Social Interests, 81 MICH. L. REV. 473, 571 (1983).

8. U.S. CONST. art. I, $\S 9$, cl. 1.

9. See, e.g., FEDERALIST No. 42 (James Madison) (referring to the clause as referencing the slave trade and decrying those who would interpret it as "calculated to prevent voluntary and beneficial emigrations from Europe to America").

10. U.S. CONST. art. $1, \S 8$, cl. 4.

11. Id. amend. XIV ("All persons born or naturalized in the United States, and subject to the jurisdiction thereof, are citizens of the United States and of the State wherein they reside").

12. See Sarah Cleveland, Powers Inherent in Sovereignty: Indians, Aliens, Territories, and the Nineteenth Century Origins of Plenary Power over Foreign Affairs, 81 TEXAS L. REV. 1, 81 (2002). 
which it was written, and deep-seated assumptions about both family and migration, none of which is still true today. Over the years, courts have developed a constitutional jurisprudence of family rights for individuals and immigration powers for the government.

For America's founders, and, indeed, for the first hundred years of the country's history, the family was a central, but unspoken, undergirding principle of democratic theory. As Nancy Cott has described it, the founders" "political theory of marriage" was "so deeply embedded in political assumptions that it was rarely voiced as a theory"; it "occupied the place where political theory overlapped with common sense." 13 At the center of this theory was the notion of marital unity. The common law "turned the married pair legally into one person - the husband." ${ }^{14}$ Under the doctrine of coverture, a married woman lost her ability to manage her own property, enter into contracts, or establish an independent domicile. A husband's authority and responsibility over his household also extended to his children. ${ }^{15}$ These family structures were inflexible status relationships. As Joanna Grossman and Lawrence Friedman have noted, "in the nineteenth century, in general, when two people married, they opted into a status that was clearly defined for them by law. ... Marriage was a public institution; the state had a heavy stake in supporting it; and its terms were, in general, controlled by law, not individuals." 16 These terms were deeply gendered; marriage slotted men and women into particular roles that it was very difficult to resist. Women who tried, like Myra Bradwell, to fashion a different role for themselves, found that the institution of marriage itself could prevent them from doing so. When Bradwell sued the State of Illinois for its refusal to admit her to the bar, the Supreme Court sided with the state. Justice Bradley famously opined that it is a woman's "paramount destiny and mission to fulfil the noble and benign offices of wife and mother." 17

13. COTT, supra note 5 .

14. Id. at 10

15. See Jill Elaine Hasday, Parenthood Divided: A Legal History of the Bifurcated Law of Parental Relations, 90 GEO. L.J. 299, 314-15 (2002).

16. JOANNA L. GROSSMAN \& LAWRENCE M. FRIEDMAN, INSIDE THE CASTLE: LAW AND THE FAMILY IN 20 ${ }^{\mathrm{TH}}$ CENTURY AMERICA 60 (2011).

17. Bradwell v. State, 83 U.S. 130, 141-42 (1873) (Bradley, J., concurring). 
The common law understanding of family was also reflected in citizenship law. In 1855, Congress passed a statute that granted automatic citizenship to a woman who married a citizen, provided she was a "free white person" as required by the naturalization statute. ${ }^{18}$ The statute also granted citizenship to the children of American male citizens. ${ }^{19}$ Conversely, the 1907 Expatriation Act took away citizenship from a woman who married a foreigner. ${ }^{20}$ This statute was famously upheld in MacKenzie v. Hare, where it was challenged by Ethel MacKenzie, a wealthy San Franciscan who had married a British citizen but remained with him in California. The Court justified her expatriation using the language of coverture. "The identity of husband and wife," it held, "is an ancient principle of our jurisprudence." 21

In the early days of the United States, this principle of family unity and the immigration power were rarely in tension with one another. The overwhelming goal of the nation was to expand its borders and settle new territory; it had not yet begun to actively restrict immigration, with the exception of ending the slave trade in 1808 and the Federalist Congress and President John Adams's attempt, through the 1798 Alien and Sedition Acts, to quash proFrench sentiment. ${ }^{22}$ The national government encouraged westward migration and immigration from Europe through acts such as the Donation Land Act and the Homestead Act. ${ }^{23}$ Sometimes these inducements mobilized the unitary family to further the goals of settlement. The Donation Land Act, for example, provided twice as many acres to married settlers as it did to single one ${ }^{24}$ with the intent to "produce a population" through the "encouragement of the women to peril the dangers and hardships of the journey." 25

18. Act of 1855, 10 Stat. 604 (reenacted as 1 Rev. Stat. 350, § 1994 (1878)).

19. Id.

20. Expatriation Act, ch. 2534, §§ 3-4, 34 Stat. 1228, 1228-29 (1907).

21. MacKenzie v. Hare, 239 U.S. 299, 311 (1915).

22. Act of July 14, 1798, ch. 74, 1 Stat. 596 (expired 1801); Act of July 6, 1798, ch. 66, 1 Stat. 577; Act of June 25, 1798, ch. 58, 1 Stat. 570; Act of June 18, 1798, ch. 54, 1 Stat. 566 (repealed 1802).

23. Oregon Donation Act, ch. 76, 9 Stat. 496 (1950), amended by Act of July 17, 1854, ch. 84, 10 Stat. 305; Homestead Act, 12 Stat. 392, 394 (1862).

24. Oregon Donation Act, ch. 76, 9 Stat. at 497.

25. Letter from Samuel R. Thurston to the Members of the House of Representatives, Thurston Papers, quoted in Richard H. Chused, The Oregon Donation Act of 1850 and Nineteenth Century Federal Married Women's Property Law, 2 LAW \& HIST. REV. 44, 58 (1984). For a more detailed analysis of the role of land acts in 
This harmony began to change in the 1870 s, when Congress passed its first exclusionary immigration statutes. At first, these targeted Chinese immigrants. ${ }^{26}$ The Chinese had come to the United States, like many immigrants, during the Gold Rush in the late 1940s, and were later recruited to build the Central Pacific Railroad. ${ }^{27}$ In 1869, the railroad was completed, and many Chinese moved to major urban centers on the West Coast. Simultaneously, a severe economic drought depressed wages and led to pervasive unemployment, and many white westerners blamed their economic troubles on the Chinese. ${ }^{28}$ Later statutes excluded categories of people (e.g., criminals, paupers, the insane, and those with communicable diseases) deemed undesirable regardless of their race or national origin..$^{29}$ These new restrictions reflected a growing anxiety about the ability of the nation to absorb people who were poor, uneducated, and members of religious minorities (Catholics and Jews). ${ }^{30}$ In sharp contrast to the previous decades, the broad consensus was that national interest now lay in selectively discouraging, rather than fostering, immigration.

The Chinese people who were denied entry or deported under these statutes actively contested the new laws. When their cases reached the Supreme Court, the Justices responded with opinions justifying federal control over immigration. As there was no direct textual support for the notion that the political branches of the federal government had this authority, the Court looked to structural arguments. "Jurisdiction over its own territory [to exclude aliens] is an incident of every independent nation. It is a part of its independence." ${ }^{31}$ So the Court opined in Chae Chan

encouraging westward migration, see Kerry Abrams, The Hidden Dimension of Nineteenth-Century Immigration Law, 62 VAND. L. REV. 1353 (2009).

26. See, e.g., Act of Feb. 18, 1875, ch. 20, § 300B, 18 Stat. 318 (reaffirming Asian immigrants' ineligibility for citizenship); Chinese Exclusion Act, ch. 126, § 1, 22 Stat. 58 (1882) (repealed 1943) (suspending migration of Chinse laborers to the U.S. for a period of ten years); Page Law, ch. 141, 19 Stat. 477 (1875) (repealed 1974) (banning the immigration of women who had entered into contracts of "lewd and immoral purposes" and setting forth enforcement mechanisms targeting Chinese women).

27. LuCy SAlyer, Laws Harsh as TIGers: CHINESE IMMIGRANTS AND THE SHAPING OF MODERN IMMIGRATION LAW 8 (1995).

28. Id. at 9 .

29. Immigration Act of 1891, ch. 551, §1, 26 Stat. 1084.

30. SELECT COMM'N ON IMMIGRATION AND REFUGEE POLICY, U.S. IMMIGRATION POliCy AND THE NATIONAL INTEREST, STAFF REPORT (1981), cited in ALENIKOFF ET AL, IMMIGRATION AND CITIZENSHIP 165 (6th ed.).

31. The Chinese Exclusion Case, 130 U.S. 581, 603 (1889). 
Ping v. United States, where it upheld the law excluding Chinese laborers from the country. The Court also analogized the immigration power to other "incident[s] of sovereignty," including the powers to "declare war, make treaties, suppress insurrection, repel invasion, regulate foreign commerce, secure republican governments to the States, and admit subjects of other nations to citizenship." 32

The Court expanded on its initial holding in another case concerning a Japanese immigrant named Nishimura Ekiu, who claimed that she was the wife of a man already in the United States. ${ }^{33}$ Her passport stated that she was traveling with him, but she clearly was not. She said she planned to go to a hotel and wait until her alleged husband met her there. ${ }^{34}$ The immigration examiner found Ekiu excludable under an 1891 statute as "likely to become a public charge." 35 She in turn claimed that principles of due process required her to be granted a hearing, but the Court, referring to the power of the "political department of the government" over immigration, rejected her claim. ${ }^{36}$ The following term, the Court expanded its understanding of immigration authority still further to the deportation context, holding that Congress's power to "expel or deport foreigners ... rests upon the same grounds, and is as absolute and unqualified as the right to prohibit and prevent their entrance into the country." ${ }^{37}$ The notion that the political branches of the federal government-Congress and the Executive-have exclusive power to regulate the nation's borders became known as the "plenary power doctrine." ${ }^{38}$ Importantly, this doctrine developed long before modern equal protection doctrine had developed. ${ }^{39}$

32. Id. at 604. For a detailed account of the development of the plenary power doctrine in Chae Chan Ping, see Cleveland, supra note 12, at 124-33.

33. Nishimura Ekiu v. United States, 142 U.S. 651 (1892).

34. Id. at 652 .

35. Id. at 662. For an exploration of the case and discussion of the treatment of unmarried women as prostitutes or paupers, see KEVIN JOHNSON, THE HUDDLED MASSES MYTH: IMMIGRATION AND CIVIL RIGHTS 126 (2004).

36. Nishimura Ekiu, 142 U.S. at 659.

37. Fong Yue Ting v. United States, 149 U.S. 698, 707 (1893).

38. See Hiroshi Motomura, Immigration Law After a Century of Plenary Power: Phantom Constitutional Norms and Statutory Interpretation, 100 YALE L.J. 545, 547, 551552 (1990) (defining plenary power and identifying these cases as the origins of the doctrine).

39. See, e.g., Plessy v. Ferguson, 163 U.S. 537 (1896) (upholding segregation as consistent with equal protection principles). 
By the time Congress began actively regulating immigration in the 1880s, the common law notion of the unitary family headed exclusively by a husband and father had begun to unravel, at least at the state law level. Many states had passed married women's property acts, which enabled wives to keep their separate property upon marriage. ${ }^{40}$ The women's suffrage movement was actively advocating for a national right to vote and western states were already beginning to allow women to vote. ${ }^{41}$ But these changes afoot represented a slow disintegration and transformation, not an overnight revolution. ${ }^{42}$ The common law theory of marital unity was still so powerful that family unity was treated with extraordinary deference-even in the face of an articulation of the immigration power that made the state's authority sound absolute.

Consider, for example, the case of Chung Toy Ho and Wong Choy Sin, the wife and child of a Chinese merchant named Wong Ham. ${ }^{43}$ Mr. Wong was a well-known Chinese merchant living in Portland, Oregon. Under the Chinese Exclusion Act and subsequent statutes, Chinese laborers were excluded from entry to the United States. ${ }^{44}$ Per treaty, some classes of Chinese people were allowed to enter, namely "teachers, students, merchants, or [people who proceed] from curiosity; together with their body and household servants." ${ }^{45}$ Those who were members of these favored classes were required by statute to obtain a certificate from the Chinese government stating the person was entitled by the statute to come to the United States and granting permission to do so. ${ }^{46}$

40. See, e.g., Act of Apr. 7, 1848, ch. 200, 1848 N.Y. Laws 307 (enabling a married woman to receive and hold to her "sole and separate use" real and personal property, removing such property from the control of the husband and protecting it from liability for his debts). (1970).

41. T.A. Larson, Woman Suffrage in Western America, 38 UTAH HIST. Q. 8, 19

42. See Reva B. Siegel, Home as Work: The First Woman's Rights Claims Concerning Wives' Household Labor, 1850-1880, 103 YALE L.J. 1073 (1994).

43. In re Chung Toy Ho, 42 F. 398 (C.C.D. Or. May 23, 1890).

44. Scott Act, ch. 1064, § 1, 25 Stat. 504 (1888) (repealed 1943) (restricting entry of all Chinese laborers); Act of July 5, 1884, ch. 220, 23 Stat. 115 (repealed 1943) (amending and adding certificate requirement to Chinese Exclusion Act); Chinese Exclusion Act, ch. 126, $\S 1,22$ Stat. 58 (1882) (repealed 1943) (suspending migration of Chinse laborers to the U.S. for a period of ten years).

45. Treaty Between the United States and China, Concerning Immigration, Nov. 17, 1880, U.S.-China, 22 Stat. 826.

46. Act of 1884, ch. 220, 23 Stat. 115. 
These statutes made no mention of wives or children. Read literally, the statutes prohibited them from entering the United States without a certificate, because " "every Chinese person,' other than a laborer," who was entitled to come had to acquire a certificate. ${ }^{47}$ It would have been very difficult for many of them, including Chung Toy Ho and Wong Choy Sin, to demonstrate that they were entering as merchants, teachers, or students; their true purpose in entering was as the family members of a merchant.

Hearing their case, Judge Deady of the District Court of Oregon construed the statute to allow their entry. He conceded that they were "'Chinese persons,' and therefore within the letter of the statute" but concluded that, in his judgment, "they are not the 'persons' contemplated by [C]ongress in the passage of the act." 48 "Chinese women," he explained, "are not teachers, students, or merchants," so obtaining the required certificate would be impossible. But, he continued, "as the wives and children of 'teachers, students, and merchants,' they do in fact belong to such class." 49 The judge also observed that the treaty allowed a merchant to bring with him his "body and household servants," and concluded that "[i]t is impossible to believe that parties to this treaty, which permits the servants of a merchant to enter the country with him, ever contemplated the exclusion of his wife and children." ${ }^{50}$ The opinion concludes by holding that if a Chinese merchant is entitled to enter the United States he is therefore entitled to bring his wife and children with him. "The company of the one, and the care and custody of the other, are his by natural right; and he ought not to be deprived of either, unless the intention of [C]ongress to do so is clear and unmistakable." 51

Thus, for Judge Deady, the "natural right" of a husband and father to the "care and custody" of his wife and child had to be considered when construing a federal statute that, on its face, demanded an opposite result. Many other cases were litigated during this period, some agreeing with Judge Deady's rationale ${ }^{52}$

47. In re Chung Toy Ho, 42 F. at 399 (examining Act of July 5, 1884, ch. 220, 23 Stat. 115 (repealed 1943)).

48. Id. at 399 (interestingly, Judge Deady's son, Paul R. Deady, represented the Chinese petitioners in the case).

49. $I d$.

50. Id.

51. Id. at 400 .

52. In re Lee Yee Sing, 85 Fed. Rep. 635 (D. Wash. 1898); United States v. Gue Lim, 83 Fed. Rep. 136 (D. Wash. 1897). 
and some rejecting it. ${ }^{53}$ In 1900, the United States Supreme Court finally addressed the issue, and sided with Judge Deady. In United States v. Mrs. Gue Lim, the Court that the wives and children of Chinese merchants were entitled to enter the United States without a certificate of their own. ${ }^{54}$ Justice Peckham, writing for the Court, observed that a Chinese wife "may have [had] no former, and may have no present, occupation or profession." ${ }^{55}$ To require her to obtain a certificate would mean that she "cannot come into this country at all .... She must come in as the wife of her domiciled husband or not at all." 56 The Court reached the same conclusion for the children of Chinese merchants, explaining, "They come in by reason of their relationship to the father." 57

The cases involving Chinese women occurred within a specific racialized context in which Congress had attempted to severely limit Chinese migration while still leaving open the possibility of trade between nations and the migration of Chinese from upper classes necessary to effect that trade. These cases can be seen as examples of how common law notions of family rights operated to protect family unity in spite of the racialized nature of the regulatory scheme. But principles of family unity also operated to exclude. The "family" protected by the principle of family unity was married and monogamous. When immigrants especially those who were nonwhite-did not fit this definition of family, the principle of family unity was no help to them. In these instances, courts questioned the legitimacy of particular family structures, and thus made palatable the exclusion of family members from entry or sometimes even citizenship. ${ }^{58}$

I do not want to overstate the extent to which the common law understanding of the unitary family was a "right." Judges such

53. In re Ah Quan, 21 Fed. Rep. 182, 186 (D. Cal. 1884); In re Ah Moy, 21 Fed. Rep. 785 (D. Cal. 1884); In re Wo Tai Li, 48 Fed. Rep. 667 (N.D. Cal. 19894); In re Lum Lin Ying, 59 Fed. Rep. 682 (D. Or. 1894); In re Li Foon, 80 Fed. Rep. 881 (S.D.N.Y. 1897).

54. United States v. Mrs. Gue Lim, 176 U.S. 459 (1900).

55. Id. at 466 .

56. Id. at 468 .

57. Id.

58. See, e.g., Collins, supra note 5 (showing how children born abroad to U.S. citizen fathers were denied citizenship when they were born in countries where some people practiced polygamy or born outside of marriage); Kerry Abrams, Polygamy, Prostitution, and the Federalization of Immigration Law, 105 COLUM. L. REV. 641 (2005) (showing how second-wives of Chinese immigrants were labeled "prostitutes" for immigration purposes and therefore excluded). 
as Judge Deady may have referred to family unity as a husband and father's "natural right," but this notion was substantially different from how we understand rights today. Before the advent of international human rights and the constitutionalization of individual rights, natural rights were part of the fabric of society and informed how courts and legislatures understood the scope of their power but were not cognizable rights on their own. Importantly, these "rights" simultaneously conferred authority on husbands and fathers and undermined the autonomy of wives and children. Sometimes, wives and children benefited from the family unity principle, by obtaining access to immigration or citizenship statuses for which they otherwise would not have been eligible. Sometimes, however, their inability to claim family reunification as an independent right meant that they lost their citizenship (as in the case of women who married foreigners) or were deprived of it in the first place (as in the case of children of nonmarital citizen fathers). Despite these important caveats, however, the "right" to family unity during this age was strikingly significant-strong enough to override serious government interests in border protection and immigration control.

\section{THE AGE OF SECURITY}

Chinese and Japanese exclusion paved the way for a more wide-ranging and robust national interest in protecting its borders. Although this interest was first framed in both statutes and case law in racial and national origins terms, and has maintained this inflection in some form or another through today, it quickly expanded to a more general authority. Under this version of the plenary power doctrine, the executive and legislative branches of the federal government had the sole power to make decisions regarding immigration with very little interference from either the states or the federal judiciary. Despite the widespread understanding that a man had the right to the services of his wife and custody and control of his children, over time, this right to family unity, still largely extraconstitutional in its framing, was outweighed by the plenary power doctrine espoused by the courts.

The first hints of just how broad plenary power could become came with the Emergency Quota Act of 1921 and the National 
Origins Act of 1924. ${ }^{59}$ Although Chinese laborers had been excluded decades before, these acts were the first that set forth quotas for all immigrants, regardless of their nation of origin. These quotas were wildly different depending on the national origin of the migrant, and were the backbone of a racist immigration regime that persisted until Congress, urged on by President Johnson, repealed the quota acts in $1965 .{ }^{60}$ To be sure, the quotas privileged family members in the immigration process, and wives had preferred status. ${ }^{61}$ For our purposes, the truly remarkable change ushered in by these quotas was the assumption made by Congress that it could restrict family migration, even the migration of families who were monogamous, Christian, and "civilized." 62

The implementation of these quotas sometimes told a different story. Judges were reluctant to impose them, and almost immediately began to create loopholes. ${ }^{63}$ Over time, however, the U.S. Supreme Court bolstered the plenary power doctrine by upholding congressional and executive action even where it was arbitrary and even where it resulted in the tearing apart of established families. Two cases in particular from the 1950s are illustrative of this trend.

In Knauff v. Shaughnessy, a German-born wife of a naturalized citizen was excluded from the U.S. without a hearing on the ground that her admission would be "prejudicial to the interests of the United States." 64 The government claimed national security interests were paramount due to "the national emergency of World War II." ${ }^{65}$ Ms. Knauff did not make a claim that her marriage was constitutionally protected. ${ }^{66}$ Indeed, there

59. Immigration Act of 1924, Pub. L. No. 68-130, ch. 190, 43 Stat. 153.; Emergency Quota Act of 1921, Pub. L. No. 67-5, ch. 8, 42 Stat. 5, repealed by Immigration Act of 1924, 43 Stat. 153.

60. Hart-Celler Act, Pub. L. No. 89-236, 79 Stat. 911 (1965)

61. Kerry Abrams, What Makes the Family Special?, 80 U. CHI. L. REV. 7, 12 (2012).

62. Id. at 12-14 (discussing effects of these acts on family migration).

63. See Kerry Abrams, Peaceful Penetration: Proxy Marriage, Same-Sex Marriage, and Recognition, 2011 MICH. ST. L. REV. 141, 156-162 (discussing judicial overriding of 1921 Quota Act for wives of immigrants who would otherwise have been excludable).

64. United States ex rel. Knauff v. Shaughnessy, 338 U.S. 537, 539 (1950).

65. Id. at 544 .

66. Id. at 542 (discussing plaintiff's claim that the statute in question and accompanying regulations contained unconstitutional delegations of legislative power). See also Adam B. Cox \& Cristina M. Rodriguez, The President and Immigration Law, 119 YALE L.J. 458, 475 (2009) (noting that in Knauff the Court found that the right to exclude aliens "stems not alone from legislative power but is inherent in the executive power to 
was no constitutional protection for marriage at this time; it would be seventeen more years before Loving $v$. Virginia ushered in a new era of constitutionalized family law. ${ }^{67}$ Instead, she made a structural constitutional claim, arguing that the regulations used were not "reasonable" and unconstitutionally delegated legislative power to the executive. ${ }^{68}$ The Court denied Knauff's claim, citing the exclusion-era cases, including Nishamura Ekiu. "It is not within the province of any court," it explained, "to review the determination of the political branch ... to exclude a given alien." 69

Three years later in Shaughnessy v. Mezei, the Supreme Court upheld the exclusion of another noncitizen, also the spouse of a U.S. citizen. ${ }^{70}$ There, Mr. Mezei, a resident of the United States, had left to visit his dying mother in Romania. ${ }^{71} \mathrm{He}$ was denied permission to enter, and was delayed for nineteen months while he tried to get exit papers to leave Hungary. ${ }^{72}$ When he attempted to reenter the U.S., he was detained on Ellis Island. Because no other country would take him, unlike Ellen Knauff, he could not leave Ellis Island. ${ }^{73}$ In Mezei, the Supreme Court reaffirmed its holding in Knauff, finding that "[w]hatever the procedure authorized by Congress is, it is due process"-even if the process was no process at all. ${ }^{74}$ This stunning articulation of plenary power as absolute control over borders arguably marks the height of the doctrine. Mezei's nascent family reunification claim (his wife was living in upstate New York and he was attempting to return to the United States after living there for years) is not even mentioned by the dissent in that case.

Even at the height of plenary power, however, the idea of family rights still held a cherished place in the popular imagination. Both Knauff and Mezei provoked controversy. Congress held hearings in which Ellen Knauff testified and was

\footnotetext{
control the foreign affairs of the nation" and characterizing this holding as "in tension with conventional understandings of separation of powers").

67. See Loving v. Virginia, 388 U.S. 1 (1967).

68. See supra note 66 and accompanying text.

69. 338 U.S. at 543.

70. Shaughnessy v. United States ex rel. Mezei, 345 U.S. 206, 217 (1953) (Black, J., dissenting) (stating that "he wanted to go to his wife and home in Buffalo")

71. Id. at 208 (majority opinion).

72. Id.

73. Charles D. Weisselberg, The Exclusion and Detention of Aliens: Lessons from the Lives of Ellen Knauff and Ignatz Mezei, 143 U. PA. L. REV. 935, 965-66 (1995).

74. Mezei, 345 U.S. at 212.
} 
ultimately granted a full exclusion hearing by the Bureau of Special Inquiry, and an appeal to the Board of Immigration Appeals-exactly what she had asked for in her Supreme Court case. ${ }^{75}$ The hearings revealed that the government had relied on hearsay and misinformation in reaching its conclusion that Knauff was engaged in espionage. The Board ordered that she be admitted to the U.S. as a permanent resident. She later sought U.S. citizenship, which the government also fought, and rather than continue litigating the issue, she lived out her days a permanent resident, but not a citizen, of the United States. ${ }^{76}$ Mezei was less successful but was also ultimately released. He had been convicted of possessing stolen goods (sacks of flour during the Great Depression), which was a "crime of moral turpitude," a ground for exclusion, and had attended meetings with communists. ${ }^{77}$ But his lawyer made a good case that he did not deserve to live out his life a prisoner on Ellis Island, and the Attorney General paroled him into the United States. ${ }^{78}$

If Mezei and Knauff show the importance of the Cold War and national security to bolstering the plenary power doctrine, Lutwak v. United States shows how changing notions of family weakened the family unity principle. ${ }^{79}$ Lutwak, decided in the same term as Mezei, involved several United States citizens who married Polish concentration camp survivors in an attempt to get them legal immigration status under the War Brides Act. ${ }^{80}$ Lutwak posed a problem for the Court: the marriages might well be valid under a formal family law test, yet they seemed to be intended to circumvent immigration law. ${ }^{81}$ The conspirators had been indicted for fraud and conspiracy to commit fraud, but only two of the three couples were convicted. ${ }^{82}$ One of the defendants was acquitted, most likely because he and his new wife began cohabiting after he was indicted, calling into question - at least for

75. Weisselberg, supra note 73, at 961-64 (1995).

76. Id. at 964 n. 165

77. Id. at $976-83$.

78. Id. at 984 .

79. Lutwak v. United States, 344 U.S. 604 (1953).

80. See War Brides Act of Dec. 28, 1945, Pub. L. 271, ch. 591, 59 Stat. 659 (1945). See also ARISTIDE ZOLBERG, A NATION BY DESIGN 304-305 (2006) (outlining history of the United States' refusal to provide refuge to displaced persons after World War II).

81. Lutwak, 344 U.S. at 609-10.

82. Id. at 605 . 
the jury - whether their marriage was really a "sham." ${ }^{83}$ They apparently expressed the wish, at trial, to remain married to each other. ${ }^{84}$

The marital unity principle had assumed that marriage was a hierarchical status relationship that produced gendered citizens. Importantly, marriage was the only legal space for sexual relations ${ }^{85}$ and despite the fact that spouses did sometimes divorce or separate, it was also understood to be permanent ${ }^{86} \mathrm{But}$ in the twentieth century, this common understanding slowly changed. Marriage began to be understood as an expression of self-authorship, reflecting a person's individuality rather than conformity. ${ }^{87}$ The rigid gender roles assigned to spouses were undermined, both by behavior and through law. This notion, however, had not yet calcified into a constitutional right. Instead, at this point in time, marriage as self-expression was a threatening idea, because it gave control to spouses to define what it meant for them, rather than what it contributed to society. Instead of being the bedrock of a defined social structure, marriage could be used to undermine these very structures.

This tension can be seen in the Court's approach to affirming the Lutwak defendants' guilt. At the time Lutwak was decided, the only existing doctrine available for determining questions of marriage fraud was the "essentials of the marriage" test from annulment law. ${ }^{88}$ This test required that one party to the marriage seek an annulment based on his or her spouse's premarital misrepresentations about his or her willingness to engage in sexual activity or procreation. ${ }^{89}$ That test didn't fit well on Lutwak's facts: none of the conspirators had been duped into

83. See Maria Isabel Medina, The Criminalization of Immigration Law: Employer Sanctions and Marriage Fraud, 5 GEORGE MASON L. REV. 669, 706 (1997) (arguing that a "fair construction of the acquittal is that the jury must have been convinced by the evidence presented that the marriage, regardless of the intent of the parties at the time they married, had become, by the time of the trial, a 'valid' marriage").

84. See Lutwak, 344 U.S. at 621 (Jackson, J., dissenting) (noting that at trial the parties expressed their desire to stay married and were acquitted).

85. Anne Coughlin, Sex and Guilt, 84 VA. L. REV. 1, 21-25 (1998).

86. For a history of spousal separation, see HENDRIK HARTOG, MAN AND WIFE IN AMERICA (2000).

87. See Kaiponanea T. Matsumura, A Right Not To Marry, 84 FordHAM L. REV. 1509, 1530-33 (2016).

88. For an extended analysis of the "essentials" test, see Kerry Abrams, The End of Annulment, 16 J. GENDER, RACE \& JUSTICE 681 (2013).

89. Id. at 686 . 
thinking that any of these marriages were about anything other than getting refugees safely out of Europe. The only other available doctrine was the slim line of cases holding that a marriage made in jest was not a valid marriage..$^{90}$ Indeed, in its opinion upholding the jury verdicts against the convicted conspirators, the Seventh Circuit made a somewhat ham-handed attempt at using the "jest" exception to describe the Lutwak facts. ${ }^{91}$ It was not only marriages made in jest that were void, according to that court, but also marriages in which the parties did not "assent to enter into the relation as it is ordinarily understood, and it is not ordinarily understood as merely a preten[s]e, or cover, to deceive others." ${ }^{" 92}$ Of course, this statement was not true: "shotgun" weddings and other marriages for a particular purpose were marriages designed precisely to "cover or deceive others," 93 and there was nothing invalid about these; in fact, marriage was often the "punishment" for the crime of seduction in nineteenthcentury family law. ${ }^{94}$

The Supreme Court upheld the Seventh Circuit's decision, but not on the theory the lower court had used. Understanding that annulment doctrine was inapposite to the facts at hand, the Court declared the actual legal validity of the marriages immaterial to the question of fraud. "No one is being prosecuted for an offense against the marital relation," Justice Minton explained.$^{95}$ Instead, the offense was that the parties had used the institution of marriage in order to gain a benefit they did not deserve. ${ }^{96}$ The marriages themselves might be legally valid, but that would not stop the government from prosecuting the parties for immigration fraud. The government did not need to defer to the individuals' understanding of what their marriage meant to them. Instead, it could impose its own view of what marriage was supposed to mean and deny the couple the benefits of marital status if they were found wanting. As the Court put it in Lutwak,

90. For a discussion of the jest exception, see Kerry Abrams, Marriage Fraud, 100 CAL. L. REV. 1, 13 (2012).

91. See United States v. Lutwak, 195 F. 2d 748 (7th Cir. 1952).

92. Id. at 753-54. See also Rubenstein v. United States, 151 F. 2d 915, 918-19 (1945) (making the same claim).

93. See Abrams, supra note 90, at 12 .

94. Melissa Murray, Marriage as Punishment, 112 CoLuM. L. ReV. 1, 24 (2012). See also Abrams, supra note 90, at 12 (discussing "limited purpose" marriages).

95. Lutwak v. United States, 344 U.S. 604, 611 (1953).

96. Id. 
"the common understanding of a marriage, which Congress must have had in mind when it made provision for 'alien spouses' in the War Brides Act, is that the two parties have undertaken to establish a life together and assume certain duties and obligations." 97

Taken together, Knauff, Mezei, and Lutwak represent a shift in the interaction of family rights and immigration power. These cases, occurring after the trauma of World War II and the beginnings of the Cold War, were decided in a context of high anxiety over borders and infiltration. A spouse might not be just a spouse but a spy. At the same time, the meaning of marriage was shifting. Divorce was increasingly available, and, toward the end of this period, nonmarital births increased. Marriage was becoming more individualistic and less central to the social order.

Indeed, we can see in the Knauff, Mezei, and Lutwak dissents, all written by Justice Jackson, the seeds of a new understanding of both family rights and immigration power. In his Knauff dissent, Justice Jackson articulated a family reunification rationale for Knauff's claims. Congress, he argued, has the power to exclude aliens. But it did not have the power to authorize "an abrupt and brutal exclusion of the wife of an American citizen without a hearing." 98 Justice Jackson painted a stark picture of the injustice he saw in the government's treatment of the Knauffs"Now this American citizen is told he cannot bring his wife to the United States, but he will not be told why,"-and the consequences of this treatment - "He must abandon his bride to live in his own country or forsake his country to live with his bride." ${ }^{99}$ Regarding the claim that national security was at stake, Justice Jackson expressed skepticism.

Security is like liberty, in that many crimes are committed in its name. The menace to the security of this country, be it great as it may, from this girl's admission is as nothing compared to the menace to free institutions inherent in the procedures of this pattern....

97. Id. at 611 .

98. United States ex rel. Knauff v. Shaughnessy, 338 U.S. 537, 550 (1950) (Jackson, J., dissenting).

99. Id. at $550-51$. 
I should direct the Attorney General either to produce his evidence justifying exclusion or to admit Mrs. Knauff to the country. ${ }^{100}$

Similarly, in Lutwak, Justice Jackson worried about the effects of creating a new class of crimes based on marriage. How could it be a criminal act, he queried, to enter into a legally valid marriage? ${ }^{101}$ If anyone had standing to contest the validity of the marriage, it was the spouses, because a fraudulent marriage, unlike a bigamous or incestuous marriage, is voidable, not void. ${ }^{102}$ The fact, he remarked, that the couple who had decided to stay together had been acquitted, and "no one contends that their marriage is void," further supported the idea that it was up to the spouses, not the government, to determine whether the marriages were valid. ${ }^{103}$ Wouldn't these parties be just as subject to prosecution if they held themselves out as single, since they had been married in what appeared to be valid ceremonies? ${ }^{104}$

\section{THE AGE OF BALANCING}

We now come to our third, and final, age, one that I have termed the "age of balancing." In contrast to the approaches in the two earlier ages, courts today recognize the importance of family ties and even recognize them as a constitutional liberty interest, while simultaneously recognizing the importance of national security interests. This recognition is beginning to lead to a more nuanced analysis in specific cases, with an understanding that even a right as important as family unity can be overridden by security concerns but that the bald claim of "national security" without more does not automatically override family interests.

In the last twenty years, two major shifts have occurred which have further reworked the balance between individual family rights and the federal immigration power. First, family rights have become constitutionalized. Second, the Supreme Court has expressed increasing skepticism that plenary power over immigration means that courts have no role whatsoever to play in evaluating the constitutionality of immigration law and

100. Id. at 551-52.

101. Lutwak, 344 U.S. at 620 (Jackson, J., dissenting).

102. Id. at 621

103. Id.

104. Id. A married person could be prosecuted if he held himself out as single if, for example, he tried to marry another, violating the criminal bigamy statutes. 
enforcement. Together, these two trends have put family rights in a stronger position than they were mid-century. To be sure, family rights never absolutely outweigh immigration concerns today, and there has yet to be a case that expressly constitutionalizes the right to family reunification in the United States. The Court, however, has indicated in multiple recent cases that the interest in family reunification is an important factor in constitutional adjudication. In other words, rather than assuming that the immigration power always outweighs family rights or that family rights outweigh the immigration power, the Court balances the interests of individuals with the interests of the state.

\section{A. The CONSTitutionalization OF FAMILY Rights}

As with many other areas of law, the twentieth century introduced a new attention to individual rights in family law. ${ }^{105}$ This transformation did not occur overnight. It began with the parental rights cases of the $1920 \mathrm{~s},{ }^{106}$ but did not fully develop until mid-century, when these rights were further entrenched and expanded. ${ }^{107}$ Beginning in the 1960s, the Warren Court, in the words of Professor David Meyer, "ushered in a dramatically different understanding of the relationship between family law and the Constitution." 108 The application of the Fourteenth

105. MARY ANN GLENDON, THE TRANSFORMATION OF FAMILY LAW: STATE, LAW, AND FAMILY IN THE UNITED STATES AND WESTERN EUROPE 88-89 (1989).

106. Pierce v. Soc'y of Sisters, 268 U.S. 510, 534-35 (1925) (affirming lower court's decision to enjoin enforcement of the Oregon Compulsory Education Act because it "unreasonably interferes with the liberty of parents and guardians to direct the upbringing and education of children under their control"); Meyer v. Nebraska, 262 U.S. 390 (1923) (holding it unconstitutional to prohibit teaching in languages other than English until the student passes the eighth grade). The Court recognizes the right to "establish a home and bring up children" as one which "may not be interfered with, under the guise of protecting the public interest, by legislative action which is arbitrary or without reasonable relation to some [state] purpose." Id. at 399-400.

107. See Smith v. Org. of Foster Families for Equal. \& Reform, 431 U.S. 816, 846-47 (1977) ("Whatever liberty interest might otherwise exist in the foster family as an institution, that interest must be substantially attenuated where the proposed removal from the foster family is to return the child to his natural parents."); Wisconsin v. Yoder, 406 U.S. 205 (1972) (holding that it was unconstitutional to compel Amish parents to send their children to high school until the age of 16 under Wisconsin's compulsory education law, due to parental interest in raising their children in accordance with their religious beliefs); Prince v. Massachusetts, 321 U.S. 158, 166 (1944) (holding that while the rights of parents are not beyond limitation, "[i]t is cardinal with [the Court] that the custody, care and nurture of the child reside first in the parents ... [in a] private realm of family life which the state cannot enter").

108. David D. Meyer, The Constitutionalization of Family Law, 42 FAM. L.Q. 529, 533 (2008). 
Amendment values of liberty and equality to a variety of family law issues led to constitutional decisions "declaring a fundamental right to marry, ensuring access to divorce, curbing discrimination based on sex and illegitimacy, and recognizing new rights for children and unwed fathers." ${ }^{109}$ Marriage, thought one hundred years ago to be a "public institution," now took on another dimension, a right that could be articulated by an individual person. ${ }^{110}$ And parental rights also took on constitutional stature, to the point where statutes that offered visitation even to grandparents could be struck down as infringing on a parent's right to care, custody, and control of his or her children. ${ }^{111}$

Professor Meyer has observed that nearly all of these cases sounded in one or both of two registers: equality or autonomy. ${ }^{112}$ Each of these concepts would have seemed inapposite in the family context to the courts of the nineteenth century. Consider again, for example, Myra Bradwell's claim, referenced earlier, that she should be admitted to the Illinois bar. ${ }^{113}$ The notion that men and women were similarly situated and should be treated equally received no traction with the Court, nor did the notion that she was an autonomous individual with the right to pursue a profession regardless of her sex or marital status. ${ }^{114}$ In contrast, constitutionalized family rights have focused on the individual's ability to operate autonomously and free from discrimination. Whether the issue is the right to marry, the right to the care, custody, and control of one's children, or the right of access to

109. Id. at 529 .

110. See, e.g., Turner v. Safley, 482 U.S. 78 (1987); Zablocki v. Redhail, 434 U.S. 374 (1978); Loving v. Virginia, 388 U.S. 1 (1967).

111. Troxel v. Granville, 530 U.S. 57, 72-73 (2000) (holding that "the Due Process Clause does not permit a State to infringe on the fundamental right of parents to make childrearing decisions simply because a state judge believes a 'better' decision could be made").

112. Meyer, supra note 108, at 533-34.

113. Bradwell v. State, 83 U.S. 130 (1873).

114. It is notable that Bradwell's claim was brought under the Privileges and Immunities Clause, which some hoped would become a vehicle for the incorporation of common law property and contract rights into constitutional rights. See Rebecca E. Zeitlow, Congressional Enforcement of Civil Rights and John Bingham's Theory of Citizenship, 36 AKRON L. REV. 717, 747 (2003) (discussing the Slaughterhouse Cases). Like the claimants in the Slaughterhouse Cases, Bradwell claimed that the Privileges and Immunities Clause required the federal government to protect her fundamental rights. See Bradwell, 530 U.S. at 137. Her claim, however, was radical for the time as women lost their contract and property rights upon marriage. See id. at 141 (Bradley, J., concurring). 
divorce, the focus is on the individual's choice, rather than the rights that accompany occupying a place in a status hierarchy. ${ }^{115}$

Constitutional family rights have had some curious features. In particular, they have been marked by a vagueness, both about the source of the right and its scope, unusual for constitutional law. Although this feature has sometimes been critiqued as a symptom of doctrinal confusion or even as evidence that constitutional family rights are invented or meritless, Professor Meyer suggests an alternative reading. Family rights are more difficult than some others to understand as individual rights claims because the state interest often stands in for the unrepresented interests of nonparties, for example, children, fetuses, co-parents, or ex-spouses. ${ }^{116}$ As Justice Sandra Day O'Connor observed, in families, "the rights of individuals are intertwined, and the family itself has a collective personality." "117 Thus, according to Professor Meyer, we see the Court "eschewing strict scrutiny's focus on compelling interests and narrow tailoring for far more indeterminate, intermediate interest-balancing."118 The result is a constitutionalized family law, but one in which balancing tests and fuzzy standards, rather than rigid rules, are the norm. ${ }^{119}$

Our most recent example of the constitutionalization of family law is the Court's 2015 decision in Obergefell v. Hodges. ${ }^{120}$ There, the Court struck down state statutes banning same-sex marriage, using the equality and autonomy principles shared by the other constitutional family cases. The majority opinion authored by Justice Kennedy, in fact, emphasizes the autonomy principle to a remarkable degree ("personal choice regarding

115. To be sure, gendered notions of the appropriate sphere for women did not end with Bradwell. See, e.g., Goesaert v. Cleary, 335 U.S. 464 (1948) (holding that since the profession of bartending could potentially lead to moral and social problems for women, it was within the state's power to bar a woman from working as a bartender unless the bar was owned by her husband or father).

116. Meyer, supra note 108, at 531 .

117. Sandra Day O'Connor, The Supreme Court and the Family, 3 U. PA. J. CONST. L. $573,576(2001)$.

118. Meyer, supra note 108 , at 568 .

119. Id. at 531 (noting that "as courts broaden the circle of constitutional protection and undertake to mediate the sometimes conflicting interests of an expanding pool of rights-holders, they will increasingly find themselves engaging in flexible, fact-sensitive interest-balancing of a sort that fundamentally recalls 'pre-constitutional' family law").

120. Obergefell v. Hodges, 135 S. Ct. 2584 (2015). 
marriage is inherent in the concept of individual autonomy") $)^{121}$ while simultaneously invoking the common law understanding of the purpose of the family ("this Court's cases and the Nation's traditions make clear that marriage is a keystone of the Nation's social order"). ${ }^{122}$

Constitutionalized family law, then, gives individuals rights vis-à-vis other individuals. These rights are often articulated as rights to access (access to marriage, access to divorce, access to parentage, access to custody - even access to abortion). The rights are conferred not based on membership in a status group (husbands, parents, "free white persons," but instead because of one's personhood, in Obergefell's terms, "dignity"). But these rights, while more focused on the individual and more broadly applicable than common law family rights, are ripe for balancing against other interests.

\section{B. The SOFTEning OF Plenary POWER}

Simultaneous with the constitutionalization of family law has been the softening of the rigid plenary power doctrine of midcentury. To be sure, the concept of plenary power still operates in immigration law. But it has weakened from the 1950s, when the Knauff and Mezei Courts could unselfconsciously hold that "[w]hatever the procedure authorized by Congress is, it is due process." 123

Several factors contributed to the softening of plenary power. Especially crucial was the Court's 1976 decision in Mathews $v$. Eldridge that articulated a new test for determining whether procedural due process had been given. Mathews essentially requires a court to balance three issues - the importance of the private interest, the risk of erroneous deprivation of that interest if the government's proposed procedures are used, and the government's interest. ${ }^{124}$ The Mathews test opened up a new constitutional space in which an individual's fundamental right was not a trump card, but instead a factor to be considered in light of government interests in regulation.

121. Id. at 2589

122. Id. at 2590

123. Shaughnessy v. United States ex rel. Mezei, 345 U.S. 206, 212 (1953).

124. 424 U.S. 319,335 (1976). 
After Mathews, some legal scholars were concerned that the doctrine would undermine fundamental rights. Rights that had seemed absolute could now be balanced against the government's interest in curtailing them, such that "balancing [could] lead to the anomalous result that an individual will have a clear due process right to no process." 125 In immigration law, however, where the norm was "no process," the Mathews test offered a new hope. The application of Mathews to the immigration context was obvious: in almost any immigration dispute, an individual's interest in entering or remaining in the country conflicted with the government's interest in efficient exclusion or removal. In 1982, the Court adopted the new balancing approach in Landon $v$. Plasencia, where it applied the Mathews test to hold that a permanent resident who transported aliens illegally across the border had not received adequate due process at her exclusion hearing. ${ }^{26}$ But the Plasencia Court stopped short of overruling Knauff, a failure that did not go unnoticed. Professor Gerald Neuman wrote that the Plasencia Court "recognized the weighty interest of a lawful permanent resident in remaining in the United States, but it also emphasized the weighty interest of the government in efficient administration of the immigration laws" and concluded, "[w]ith that alternative analysis available, the Knauff doctrine is not only brutal, but unnecessary."127

Even in instances where the Court did not explicitly adopt the Mathews test, it did begin to find ways to adjudicate immigration cases without overruling the plenary power doctrine head-on. In many cases it interpreted statutes using what Professor Hiroshi Motomura termed "phantom constitutional norms," thus avoiding the plenary power doctrine but upholding the rights of immigrants. ${ }^{128}$ Consider, for example, Zadvydas $v$. Davis, a case in which the Court held that an alien could not be detained indefinitely if unlikely to be removed in the foreseeable

125. Martin H. Redish \& Lawrence C. Marshall, Adjudicatory Independence and the Values of Procedural Due Process, 95 YALE L.J. 455, 472 (1986).

126. Landon v. Plasencia, 459 U.S. 21 (1982).

127. Gerald. L. Neuman, Habeas Corpus, Executive Detention, and the Removal of Aliens, 98 COLUM. L. REV. 961, 1053 (1998).

128. Hiroshi Motomura, Immigration Law After a Century of Plenary Power: Phantom Constitutional Norms and Statutory Interpretation, 100 YALE L.J. 545, 549-60 (1990) (arguing that the Supreme Court has undermined the plenary power doctrine by rendering "subconstitutional" decisions in statutory interpretation cases). 
future. ${ }^{129}$ On its face, the text of the statute in question did not provide a time limit for detention. Rather than strike down the statute as unconstitutional, Justice Breyer, read into the statute a six-month limit on detention. ${ }^{130}$ In doing so, he referenced the doctrine of constitutional avoidance: "when an Act of Congress raises 'a serious doubt' as to its constitutionality, 'this Court will first ascertain whether a construction of the statute is fairly possible by which the question may be avoided."'131

The Zadvydas majority also made another important move that distinguishes that case from Knauff, Mezei, and other early plenary power cases. The majority did not treat the political branches' authority over immigration as monolithic but instead as closely linked to foreign affairs and national security interests. Thus, rather than simply defer because the subject of "immigration" was at issue, the Court examined the foreign affairs or national security issue at play in the case and considered it in light of the individual's liberty interest in not be indefinitely detained. In Zadvydas, the legitimate government foreign policy interest was in the "sensitive' repatriation negotiations" in which the executive branch might be engaged with countries that might agree to repatriate the detained aliens. ${ }^{132}$ The Court found no evidence that a habeas court's hearing a claim of unlawful indefinite detention would harm these negotiations. ${ }^{133}$

Plenary power is still very much alive. Courts give much greater deference to the executive and legislative branches in cases involving immigration, especially in cases involving immigrants who are outside the country or who have not yet been granted lawful permanent residency. But the shifts that have occurred in the last fifty years have made the doctrine more malleable and nuanced. Courts are now able to consider both the strength of the individual rights claim made by a citizen or

129. Zadvydas v. Davis, 533 U.S. 678 (2001) (reading statute to forbid indefinite detention of aliens who are unlikely to be removed in the foreseeable future).

130. Id. at 701 .

131. Id. at 689 (citing Crowell v. Benson, 285 U.S. 22 (1932)). Justice Breyer chose six months as the time limit because Congress had assumed in a previous statement that a lesser time might be unconstitutional. We do have reason to believe, however, that Congress previously doubted the constitutionality of detention for more than six months. Zadvydas at 701 (citing Juris. Statement of United States in United States v. Witkovich, O. T. 1956, No. 295, pp. 8-9).

132. Zadvydas, 533 U.S. at 696.

133. Id. at 696. 
immigrant and to interrogate with specificity the government interest asserted. This approach leads to a balancing of interests rather than a rigid rule of deference to the political branches.

\section{Individual Rights AND MOdified PlenARy POWER}

So, what happens today when individuals make family reunification claims and Congress or the executive counters with a demand that courts defer to its immigration power? In order to see the difference between the new "age of balancing" and the "age of the security state," let us examine the cases from the 1970s until today that have pitted family rights against immigration authority.

Our story begins with Fiallo v. Bell, a 1977 case in which three sets of fathers and their nonmarital children brought equal protection challenges to provisions of the Immigration and Nationality Act ("INA") defining the words "parent" and "child" for immigration purposes. ${ }^{134}$ Under the statute as then-written, these fathers did not quality as "parents" and their sons did not qualify as "children" because the fathers had not formally legitimated them. Had the American citizen or resident parents been mothers, not fathers, the relationships would have been recognized for immigration purposes. Fiallo was argued during the heyday of equal protection challenges of both gendered statutes and statutes discriminating on the basis of "illegitimacy." The statute in question in Fiallo did both at once. ${ }^{135}$ Despite its rejection of statutes discriminating on the basis of gender or illegitimacy in other contexts and its application of an emerging standard of "intermediate scrutiny" in those instances, the Fiallo court refused to apply heightened scrutiny in the immigration context. Instead, it held that even though

it could be argued that the line should have been drawn at a different point and that the statutory definitions deny preferential status to parents and children who share strong family ties ... it is clear from our cases ... that these are policy questions entrusted exclusively to the political branches of our Government, and we have no judicial authority to substitute our political judgment for that of the Congress. ${ }^{136}$

134. Fiallo v. Bell, 430 U.S. 787 (1977).

135. Id. at 794 (citing petitioners' argument that the discrimination against them was "double-barreled" discrimination).

136. Id. at 798 . 
Fiallo appears at first glance to be a simple affirmation of the plenary power doctrine in the extreme form in which it appeared in Knauff and Mezei. But a closer reading reveals a crack in the doctrine. Replying to dissenting Justice Marshall's argument that Fiallo required heightened scrutiny because it involved claims made by American citizens, Justice Powell, writing for the majority, cited Kleindeinst v. Mandel, a 1972 case in which American professors claimed a First Amendment associational right to meet with a visiting scholar in person on U.S. soil. In denying this claim, the Court held that

when the Executive exercises this [delegated] power negatively on the basis of a facially legitimate and bona fide reason, the courts will neither look behind the exercise of that discretion, nor test it by balancing its justification against the First Amendment interests of those who seek personal communication with the applicant" ... [w] can see no reason to review the broad congressional policy choice at issue here under a more exacting standard. ${ }^{137}$

In other words, under Mandel and Fiallo, the Court does not give exacting scrutiny or engage in direct balancing between the individual interest and the government interest. Instead, the government gets the first crack at framing its decision to exclude an immigrant as "facially legitimate and bona fide," and once it has done so, the individual does not have an opportunity to claim discrimination.

This articulation of the plenary power doctrine, while still affording great deference to Congress, differs significantly from that set forth in Knauff and Mezei. There, that "[w]hatever the procedure authorized by Congress is, it is due process." 138 Here, the alleged purpose of the law had to be based on a "facially legitimate and bona fide reason," potentially opening the door for the striking down of statutes not based on "facially legitimate" or "bona fide" reasons. Gerald Neuman interpreted this language as "roughly equivalent to the rational basis test" - surely a step up from no scrutiny at all. ${ }^{139}$ This version of plenary power also puts Congress above the executive in importance, treating the executive's power over immigration as "delegated" from

137. Id. at 794-95 (citing Kleindeinst v. Mandel, 408 U.S. 753, 770 (1972)).

138. Shaughnessy v. United States ex rel. Mezei, 345 U.S. 206, 212 (1953).

139. Gerald L. Neuman, The Lost Century of Immigration Law (1776-1875), 93 COLUM. L. REV. 1833, 1839 n.31 (1993). 
Congress rather than independently held. Indeed, in the years since Mandel and Fiallo, the rational basis test itself has become much more capable of invalidating statutes than it used to be. In cases such as Romer v. Evans and United States v. Windsor, the Court invalidated statutes because they were animated by a "bare desire to harm" individual people. ${ }^{140}$ If Fiallo stands for the principle that, in the immigration context, discrimination claims get rational basis review, Romer and Windsor show us that rational basis review is not a green light for the statute's constitutionality.

Despite its nuancing of the plenary power doctrine, Fiallo usually has been interpreted as supporting plenary power principles. ${ }^{141}$ None of the families who brought claims in the case prevailed. This was a disappointing result for those who wanted the courts to be robust defenders of equal protection. The Court's opinion was also disappointing to those who had hoped that the claim of constitutional family rights could outweigh the political branches' immigration authority. ${ }^{142}$

By the time the Court again considered sections of the INA that discriminated based on gender and illegitimacy, however, the constitutional architecture of gender discrimination claims was more firmly fixed. In Nguyen v. INS, the majority opinion was able to state with confidence that "in order to pass constitutional muster, the statutory provision must be substantially related to the achievement of important governmental objectives"- the now-standard "intermediate scrutiny" test. ${ }^{143}$ Nguyen involved

140. See United States v. Windsor, 133 S. Ct. 2675 (2013) (striking down Defense of Marriage Act and finding evidence of a "bare desire to harm" gay and lesbian couples in the legislative history of the act); Romer v. Evans, 517 U.S. 620 (1996) (striking down Colorado Constitutional Amendment 2, which banned the state and its municipalities from treating sexual orientation as a protected class and holding that the law in question's "sheer breadth is so discontinuous with the reasons offered for it that the amendment seems inexplicable by anything but animus toward the class it affects; it lacks a rational relationship to legitimate state interests").

141. See, e.g., Kristin A. Collins, Deference and Deferral: Constitutional Structure and the Durability of Gender-Based Nationality Laws, in THE PUBLIC LAW OF GENDER 73, 73 98, 77 (Kim Rubenstein \& Katharine G. Young eds., 2016) (describing Fiallo as "an important plenary power case" and examining the relationship between the Court's decision and subsequent Congressional action).

142. See, e.g., Kenneth L. Karst, The Freedom of Intimate Association, 89 YALE L.J. 624, 649 n.123 (1980) (describing Fiallo as "[a] case in which the Court got this subject all wrong").

143. In Nguyen v. INS, the majority was able to state with confidence that "[f]or a gender-based classification to withstand equal protection scrutiny, it must be established 
the provision in the INA that required legitimation or other stringent proofs of paternity in order for fathers to transmit citizenship to their nonmarital children born abroad without similar requirements for citizenship transmittal by U.S. mothers to their foreign-born, nonmarital children. The majority found that the differential treatment of fathers and mothers in the statute passed intermediate scrutiny because of the biological differences between men and women: "in the case of the mother, the relation is verifiable from the birth itself" but in the "case of the father, the uncontestable fact is that he need not be present at the birth" and could therefore be required to demonstrate fatherhood through other means. ${ }^{144}$

Although Nguyen was a blow to advocates of gender equality, it may have represented yet another chink in the armor of plenary power. Rather than invoke the doctrine, the Court chose to treat the claim as a straight-up gender discrimination claim, and applied intermediate scrutiny with no mention of giving deference to a "facially legitimate" or "bona fide" reason as in Fiallo. The reasons for this were not clear. It is possible that the Court did not believe that the plenary power doctrine applied to a case concerning citizenship, rather than immigration. But it is also possible that the Court did not believe it appropriate to apply plenary power principles to a case involving family relationships that bore such a tenuous relationship to national security. ${ }^{145}$

More recently, additional evidence has mounted that the Supreme Court no longer views plenary power as a doctrine that always trumps family claims. In 2010, it heard the case of FloresVillar $v$. United States, another challenge to the INA's derivative citizenship provisions. ${ }^{146}$ In this case, which concerned differential residency requirements for nonmarital fathers and nonmarital mothers, it was much more difficult for the government to assert

at least that the [challenged] classification" serves important governmental objectives and that the discriminatory means employed are "substantially related to the achievement of those objectives." Nguyen v. INS, 533 U.S. 53, 60 (2001) (internal quotation marks omitted).

144. Id. at 62 .

145. For a version of this argument, see Kerry Abrams, Immigration Law and the Regulation of Marriage, 91 MINN. L. REV. 1625, 1708 (2007) (urging courts to consider "whether the immigration provision in question is advancing core immigration policy goals or instead has ventured outside these goals into an area that has traditionally been within the province of the states").

146. Flores-Villar v. United States, 564 U.S. 210 (2011). 
a biological difference between men and women that would survive intermediate scrutiny. Why would U.S. citizen mothers be more likely to be loyal to the United States after one year of residence than U.S. citizen fathers? The court, absent Justice Kagan who recused herself based on her previous involvement in the case, split 4-4 and issued a per curiam affirmation of the Ninth Circuit's opinion with no opinion. Although this decision meant that the law did not change, it was a hint that at least four members of the Court-likely including Justice Kennedy, the author of Nguyen-believed neither that the statute was justified under intermediate scrutiny nor that the case required the expansive discretion afforded under the plenary power doctrine. As Kevin Johnson put it soon afterward: "A near-majority of the Court, which would likely have been a majority if Justice Kagan had not recused herself, appeared to be ready to limit, if not eliminate, the scope of the doctrine."147

This development came to fruition in 2017, when the Court issued its opinion in Sessions v. Morales-Santana, a case that was factually very similar to Flores-Villar and one that challenges the differential residency requirements for men and women. ${ }^{148}$ At oral argument, the Justices seemed uninterested in hearing plenary power arguments; the government's attorney attempted twice to frame the case as one about "Congress's plenary authority" but the Justices quickly turned the conversation to scrutiny of the government's stated interests in the case and whether gender or illegitimacy discrimination existed. ${ }^{149}$ In her majority opinion, Justice Ginsburg adopted this approach. Applying the intermediate scrutiny standard usually employed in gender discrimination cases, the Court struck down what it characterized as a "stunningly anachronistic law."150

Nguyen, Flores-Villar, and Morales-Santana, of course, are all cases about derivative citizenship, not about immigration. Although derivative citizenship and immigration cases flow from the same statute, the Immigration and Nationality Act, there is an argument that derivative citizenship cases are simply not subject

147. Kevin Johnson, Immigration in the Supreme Court, 2009-2013: A New Era of Immigration Law Unexceptionalism, 68 OKLA. L. REV. 57, 78 (2015).

148. Sessions, Attorney General v. Morales-Santana, No. 15-1191 (U.S. June 12, 2017).

149. Oral Argument, Lynch v. Morales-Santana, (U.S. No. 15-1191) https://www. oyez.org/cases/2016/15-1191.

150. Morales-Santana, slip op. at 14. 
to the plenary power doctrine, because they concern a person's identity at birth, not their desirability as an immigrant. Individuals born on American soil are similarly citizens under the Fourteenth Amendment of the U.S. Constitution, and the political branches of the federal government have no authority to divest them of citizenship based on national security or foreign affairs concerns. Derivative citizens are arguably similar-members of our community whether the government likes it or not. (A potential counterargument is that, absent statute, they would not be citizens at all, and the statute must come from Congress.) So, assuming for the moment that we can discount the holdings in Nguyen and Flores-Villar and the prospective holding in Morales-Santana, where do Knauff, Mezei, and Fiallo stand today? The answer is that, although they have not been directly overruled, they have been substantially undermined through the general softening of the plenary power doctrine as discussed above, and in particular through the Court's holding in Kerry v. Din, a 2015 case in which the Court considered a family reunification case brought by a U.S. citizen woman.

In Din, Fauzia Din, a naturalized U.S. citizen who had come to the United States as a refugee from Afghanistan, petitioned for a visa for her husband, Kanishka Berashk. ${ }^{151}$ His visa was denied, and the only reason given was reference to the page and a halflong anti-terrorism provision of the INA, a broad provision of the statute that makes a person inadmissible for engaging in activities ranging from blowing up a plane to lending money to someone who is engaged in terrorist activities. With no way to know what facts (true or false) were the basis of the denial, Din sued for a better explanation. Her request was not that Berashk be admitted but that she receive a better explanation than she had been given, presumably so that she could marshal a rebuttal if the government had been misinformed.

First, the bad news for Din: she lost. Five Justices upheld the government's decision to give her only the information that her husband was denied admission based on the anti-terrorism statute. Justice Scalia wrote a plurality opinion, but garnered only two votes in addition to his own. He argued that a spousal reunification claim could never be brought successfully under the Due Process Clause, regardless of whether terrorism was at

151. 135 S. Ct. 2128,2129 
issue. ${ }^{152}$ Justice Breyer, joined by three other Justices, dissented. He would have required the Court to apply the Mathews v. Eldridge balancing test and consider her request in light of government interests. ${ }^{153}$

Justice Kennedy, joined by Justice Alito, concurred. Kennedy's concurrence invokes the same language from Mandel relied upon in Fiallo but with an important addition. Once the government has offered a "facially legitimate and bona fide reason" for its decision, the opinion explains, "courts will neither look behind the exercise of that discretion, nor test it by balancing its justification against' the constitutional interests of citizens the visa denial might implicate." 154 At first glance, this simply sounds like Fiallo redux. But then Justice Kennedy adds an important caveat: "This reasoning has particular force in the area of national security, for which Congress has provided specific statutory directions pertaining to visa applications by noncitizens who seek entry to this country." 155 Every other inadmissibility provision in the INA, he notes, requires the government to indicate the "specific provision or provisions of law under which the alien is inadmissible," unless the visa application is denied due to national security or terrorism concerns. ${ }^{156}$ Justice Kennedy's opinion, while rejecting the application of a balancing test by the Court in this instance, ratifies the balancing already done in the creation of the statute by Congress-providing more individual process where national security interests are less prominent-and implies that the Court might not be so deferential in a case not so closely linked to national security. ${ }^{157}$

So what are we to make of Din? Some scholars have seen the case as a reaffirmation of the plenary power doctrine. ${ }^{158}$ Others have argued that, although it did not "kill" plenary power, it dealt

152. Justice Scalia was consistent across cases in his insistence that there is no constitutional right to the protection of the family. I explore his jurisprudence in more depth in Kerry Abrams, The Rights of Marriage: Obergefell, Din, and the Future of Constitutional Family Law, 102 CORNELL L. REV. (forthcoming 2017).

153. Din, 135 S. Ct. at 2145 (Breyer, J., dissenting).

154. Id. at 2140 (Kennedy, J., concurring).

155. Id. at 2140

156. Id. at 2141 (citing 8 U.S.C. $\$ 1182(\mathrm{~b})(1)$ and (3)).

157. Justice Kennedy specifically mentions that Din "admits in her Complaint that Berashk worked for the Taliban government" and argued that this fact "provides at least a facial connection to terrorist activity." Id. at 2141.

158. See David A. Martin, Why the Plenary Power Doctrine Endures, 68 OKLA. L. REV. 29 (2015). 
it an important blow. Michael Kagan, for example, has argued that "Din's defeat shows that plenary power is not dead yet. But Din came very close, winning four justices." 159 He points out as well that Justice Scalia and the two who joined him avoided discussing plenary power at all, instead attacking substantive due process (also perhaps this was to bolster their dissents in the Obergefell opinion, which came down eleven days later). Perhaps most important, however, is Justice Kennedy's willingness in his concurrence to assume, for the sake of argument, that Din did have a due process interest in her relationship with her spouse. ${ }^{160}$ Given his majority opinion in Obergefell, which he was presumably drafting simultaneously with his concurrence in Din, it would have been difficult to contend that an American citizen had no constitutional interest in her own marriage. The question, given the constitutional liberty interest enjoyed by Obergefell, Din, or anyone, then became not whether Din had such an interest, but how it would be balanced against the national security interests asserted by the government. For the time being, in this particular context of alleged terrorist activity, the result of the fractured opinions in Din is that the political branches continue to be allowed to engage in that balancing internally. But the implication of Kennedy's Din concurrence is that if the political branches stray too far from their national security interests, the Court will interfere.

\section{CONCLUSION}

Scholars have been predicting the end of plenary power for decades. ${ }^{161}$ Around 2000, an avalanche of scholars insinuated that the plenary power doctrine was near its demise. ${ }^{162}$ But, as Kevin Johnson has observed, after the attacks of September 11, 2001, Congress imposed "special registration" on Muslims. ${ }^{163}$ Similarly, just after his inauguration as our forty-fifth president, Donald J.

159. Michael Kagan, Plenary Power is Dead! Long Live Plenary Power, 114 MICH. L. REV. FIRST IMPRESSIONS 21, 22 (2015).

160. Din, 135 S. Ct. at 2139 (Kennedy, J., dissenting).

161. See, e.g., Stephen H. Legomsky, Immigration Law and the Principle of Plenary Congressional Power, 1984 SUP. CT. REV. 255 (1984).

162. See, e.g., Cornelia T.L. Pillard \& T. Alexander Aleinikoff, Skeptical Scrutiny of Plenary Power: Judicial and Executive Branch Decision Making in Miller v. Albright, 1998 SUP. CT. REV. 1 (1998).

163. Johnson, supra note 147, at 61 (citing Registration and Monitoring of Certain Nonimmigrants, 65 Fed. Reg. 52584, 52585 (Aug. 12, 2002)). 
Trump issued an executive order restricting immigration from seven majority-Muslim countries. ${ }^{164}$ The executive order directly impacted families with cognizable reunification claims. At this juncture, it is impossible to predict with any certainty how our current Supreme Court would view a challenge to this type of restriction, much less how a Court that includes Trump-appointed Justices will view it.

Two observations bear making, however. The first is that the Roberts Court, although often considered to be fairly conservative, has overseen a time of expansion of family constitutional rights via Windsor and Obergefell and simultaneously a time of incremental diminishment of plenary power. Professor Johnson recently characterized the Roberts Court as one that "consistently has applied ordinary, standard, and unremarkable legal doctrines in ordinary, standard, and unremarkable ways" in its immigration decisions. ${ }^{165}$

Second, constitutional law moves slowly. Although the LGBTQ rights movement appears in hindsight to have changed public opinion about same-sex marriage overnight, the seeds of this sea change were sown when the hierarchical understanding of family embraced by the common law began to morph into an individual rights-based paradigm. The development of a modern family reunification right has occurred slowly but is now ripe enough to be poised for affirmative recognition by our courts. If the judiciary continues to provide a check on the executive and legislative branches-as it has since the founding-we should expect to live in the age of balancing for quite some time.

164. Trump's Executive Order On Immigration, Annotated, NPR (Jan. 31, 2017, $10: 46$ AM), http://www.npr.org/2017/01/31/512439121/trumps-executive-order-on-immigrationannotated.

165. Johnson, supra note 147 , at 62 . 